\title{
Valorisation and Development of Local Potential Through A Sustainable Tourism Scenario in South Sumatera
}

\author{
Listen Prima*
}

Leibniz Universität Hannover; Universitas Sriwijaya, Bukit Besar Campus, Palembang, South Sumatra, Indonesia

\begin{abstract}
Ineffective local development due to globalisation and urban agglomeration causes a significant gap between urban and rural areas. The need to promote the contribution of local development in rural areas has been a topic of debate and could be fulfilled by an innovative method. This research proposes a village alliance as the innovative framework to analyse the local potential within the case study area of Lubuk Sepang Village, South Sumatera Province, Indonesia. The framework of village alliance fits in the sustainability concepts that integrates Lubuk Sepang Village with eight other villages as an alliance as well as an applicative method that is representative of most dominant context of the rural area development, especially in Indonesia. Regarding the local potential, this research uses a case study method to explore a sustainable tourism scenario by using multiple tools: field survey, expert interviews, maps analysis, and SWOT analysis. The research aims to explore the local potential and outline the integration of the heritage richness with other potential elements based on the tourism advancement perspective. The result is an initial stage for the prospective method of protection, valorisation, and development of the local heritage richness.
\end{abstract}

Keywords: local potential, village alliance, case study, tourism scenario

\section{Introduction}

Effects of globalisation bring significant changes in development, including local spatial development. The changes trigger an environmental degradation [1]. In Indonesia, the local spatial development has been changing due to domination of mass settlement and industrial buildings. South Sumatera Province as one of the provinces in Indonesia which has significant richness of local characteristics, the area's local values are especially threatened by environmental degradation. It influences the quality of the local spatial development as well.

\footnotetext{
* Corresponding author: listenprima@gmail.com
} 
Lubuk Sepang Village has the special characteristics of heritage buildings, historical settlements, and specific sceneries. Daily activities of the local people also reflect the village's unique values, such as traditions, rituals, and ceremonies. Along with its natural resources, this village offers an authentic view and knowledge of agriculture, farms, and forest as part of the daily life. Besides, this village has a strategic location near Lematang River, which is the biggest river in Lahat Regency. Furthermore, the local values might be conceptualised as developmental assets that bring a potential for the local development.

One of the significant opportunities of the local values is as subject of cultural heritage tourism. Moreover, the cultural heritage has a function as a driver of sustainability development [2]. The link between architectural heritage with social, culture, economic and political aspect brings positive impact to the local economic development as well as social and cultural values preservation.

However, the existence of those characteristics is threatened by extinction, demolition, and dismissal. Their vulnerable condition not only threatens the existence of that richness but also the local characteristics as part of national identity. Those complex elements due to urban growth and its phenomenon trigger the need for an innovative and creative method to solve the problem, such as scenario strategy. Additionally, "governance and planning were identified as critical to transformative changes towards urban sustainability" [3]. Furthermore, rapid transformation of technology as well as cultural change push the need for the scenario strategy as the more creative and innovative strategy to anticipate the future transformation and its uncertainty by providing the possible alternatives [4].

\section{Research Aim}

The research aims to explore the local potential of the case study area. The local potential can be defined as the integration of the relevant elements. The relevant elements have the most valuable characteristics for the case study area regarding the identity, as well as the prospective sectors for the maximum contribution to the local development in its future needs. Those relevant elements are architectural heritage, local and spatial development, and natural resources. Hence, the integration can be formulated as the basic concept for the advancement of extended cultural heritage tourism.

The local richness of the distinctive architectural heritage in the case study area triggers the idea of cultural heritage tourism. However, the cultural heritage tourism could be extended based on the sustainable development concept. The extension could be by integrating the form of cultural heritage tourism with other perspectives of the local development as a solid collaboration in the frame of a sustainable tourism scenario.

Furthermore, the research explores the interactions by integrating the local potential of architectural heritage with other components of immaterial heritage, such as culture, traditions, rituals as well as components of the local spatial, social, economic, politic and ecological development. Those interactions could be implemented as local knowledge in various programmes in the sustainable tourism scenario, for example through an education program. This program would offer the local knowledge as the source of education in a new package of tourism activities. Hence, the other possible collaboration is between the architectural heritage with natural resources, which could be implemented as programmes of food and wood production in the sustainable tourism scenario. The program of food production is connected to the main production of the local agricultural system. The local food production performs an important role in showing how the local people fulfil the daily need through the traditional agricultural system as well as part of the tradition, such as traditional food and cooking materials and methods. Besides, the program of wood production has strong relevance between the potential of the local forest and the dominant material of the heritage houses for the structures and ornaments. Thus, this research outlines 
those interactions between heritage, both material (architectural heritage) and immaterial (culture, traditions, rituals) with the other local potential perspectives (spatial, social, economic, politics, ecological, and natural resources) as the components of sub scenarios of the sustainable tourism scenario.

Regarding the implementation of the sustainability concept, this research offers the outlook of a village alliance idea as the framework of the case study method in the next phase of the research. In particular, this step of research introduces the concept of village alliance, as well as outlines a focused analysis of local potential through a sustainable tourism scenario. The focused analysis could be used to advance local tourism in a village alliance. In the next step, this analysis will be integrated with other focus analyses to outline the most suitable prospective method of protection, valorisation, and enhancement of the local heritage to promote the local development in the village alliance.

\section{Materials and Methods}

The methodological framework in this research uses case study method of Lubuk Sepang Village. Case study method consists of some variables of the local potential such as architectural heritage, local development, as well as natural resources. Robert. K. Yin [5] defines the case study as the empirical study which investigates the phenomena and context in real life and has indefinite limits. Moreover, the case study opens chances to construct the complex dynamics of research element [6]. The case study consists of multiples tools in a sequence of steps, such as field survey, expert interviews, maps analysis, SWOT analysis and sustainable tourism scenario. Moreover, the sustainable tourism scenario outline is evaluated to determine its efficacy.

Regarding complex elements of the case study in Lubuk Sepang Village, the analysis starts from the field survey. The field survey consists of an analysis of capacity and potential of Lubuk Sepang Village as the axis of the village alliance along with the three elements of territories, people and culture, and building construction. The field survey also covers the analysis of context. The analysis of context describes the background of the existing case study areas regarding architectural heritage, social welfare, economic development, environment quality, and natural resources, such as agriculture and landscape.

To gather input from experts in the case study area, interviews were conducted with the homeowners. There are 63 residents involved with the interviews. The interviews covered structured and semi-structured questions relate to architectural heritage, both material and immaterial issues which closely related to the topic of topic about the sustainable local development.

In addition, the maps analysis is used to communicate a scale of the case study area. It describes the alliance with its coverage of nine villages, as well as the heritage buildings in Lubuk Sepang Village as the axis of the alliance. At a smaller scale, this method supports the analysis of how existing heritage buildings are distributed and classified based on recent modifications and specific purposes. The distribution and classification of the heritage buildings is significant for the analysis of the vulnerability and the outline methods in the explorative scenario.

These tools allow for the Strength Weaknesses Opportunities Threads (SWOT) analysis to define all of the considerate components of the tourism scenario. In this method, components of space, social, economic, culture, as well as spatial planning and government are linked.

Hence, scenario planning is outlined after analyses process. "The scenario can be considered as an experimental stage set for design and planning practise, and a conceptual framework for disciplinary development" [7]. Analyses result describes influence components of the scenario planning regarding future needs in local development. The 
process of scenario planning is collaboration of limits/weaknesses of the local area with the creativity and sensitivity to implemented it in certain innovative way [8].

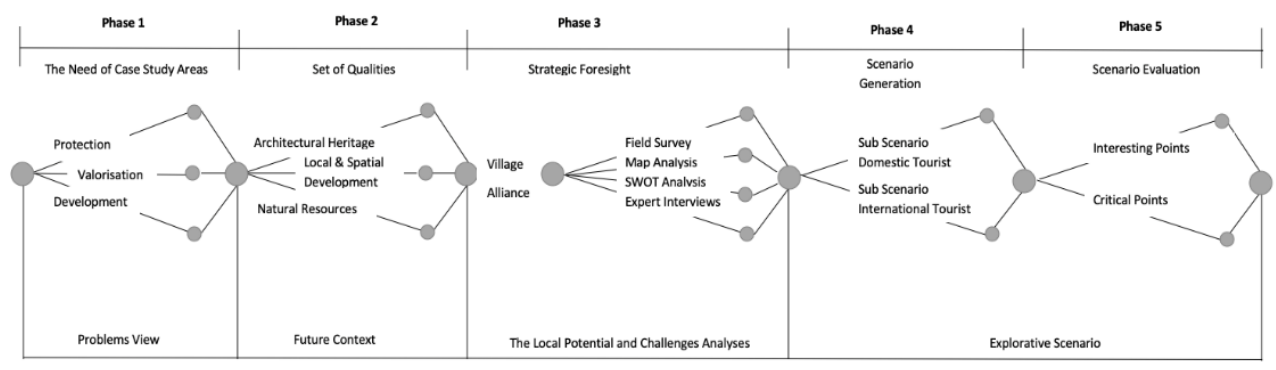

Fig 1. The process of scenario planning (Listen Prima, 2018)

There are five phases of the scenario planning (Fig 1). The first phase is determining the needs of the case study areas. The second phase is setting qualities of the future context as the integrated components of architectural heritage, local and spatial development, and natural resources. The third phase is analysing local potential through some tools in the village alliance framework. The fourth phase is generating scenarios as the proposed framework to valorise the local potential of the architectural for tourism. The last step is evaluating that scenario to outline interesting and critical points. It is significant input for scenario planning in further steps of the research.

\section{Theories}

This section explores theories and research that relate to architectural heritage, local development, and natural resources. Architectural heritage could be a form of vernacular heritage containing indigenous knowledge and is built on the relationship between the local values and eco-social factors [9]. Those characteristics are potential assets to bring out as the objects and tools to set up the local activities for conservation as well as industry [10]. However, the idea of heritage protection has triggered various debates. One of the main ideas is about whether urbanism seeks to destroy ancient urban ensembles or strives to preserve their conceptual identity [11]. Another debatable question is "the continuity and historicity of identity challenged by the immediacy and intensity of global cultural confrontations" [12]. An effect of these confrontations is a modernisation that eliminates history and beauty of the heritage buildings and sites. As Robert Hewison [13] says "the effect of modernisation was not just that everything had changed, but that everything had become more and more the same, as architectural and scenic differences were ironed out under the weight of mediocrity and uniformity." Modernisation seeks to commodify the heritage it has destroyed, turning it into a tourist attraction without reflecting its local values.

Regarding local development, there is a strong potential for cultural tourism offered by architectural heritage sites to bolster local economies; the tourism industries are as important as other industries [14]. The character, values, and uniqueness of heritage provide the power behind the tourism development. Meanwhile, the potential of heritage tourism may improve the economic condition of the local area. It also contributes a reorientation of economic benefit to specific sectors. As mentioned, the main objectives of the local development are really to improve the life of the people in the given area [15]. The local development supports the wellbeing improvement of the poor and caters the raw materials support to the urban development [16]. However, the intervention of the supporting factors is needed. The physical business infrastructure could support the local development [17]. Hence, the local 
potential of the historical, spatial, and structural, including landscape element of the local villages or peripheral area will be optimally explored for the local development.

Moreover, to examine the goals of sustainable development, it is important to measure the link between environmental development and human needs in the future. In Indonesia, this issue has political and socio-economic obstacles and the obstacles continue to the present. Besides, there are other elements to be considered to support the sustainable development locally, such as infrastructure and ecological protection, energy efficiency, and extended networks of local development [18]. Additionally, there are some principles to be considered in enhancing the tourism development, such as encompassing natural, built and cultural components, and meeting the needs of the local host community by improving the living conditions and quality of life [19]. According to Slee et al [20] and World Heritage Convention [21] tourism development of heritage sites should reflect and respect the scale, nature and distinct character of the local people; support a wide range of local economic activities; not obliterate the natural and cultural environment and balance the need of the visitors. Thus, the development activities must be based on local value systems.

Hence, natural resources have significant role in planning process of local development. Considering local potential in case study area, agriculture and forestry are major resources which highly contribute to the local income. As mentioned in OECD working papers [22] "traditionally agriculture and forestry were central to rural life as the main sources of income within the rural economy and indirectly had powerful influence on traditions, power structures and life styles to determined rural land use and landscape." However, the recent problem that "agriculture has declined sharply and gross domestic product plays an increasingly important role in rural household livelihood strategies" [23]. It has not only affected the local food production, but also in the bigger scale of the national food security. Thus, the enhancement of local landscape quality and quantity, especially towards the local natural resources production, it significantly supports the strategic planning of local development. 


\section{Result}

Based on the exploration of material and methods of this research, there are two issues as result: the local potential, and sustainable tourism scenario.

\subsection{The Local Potential}
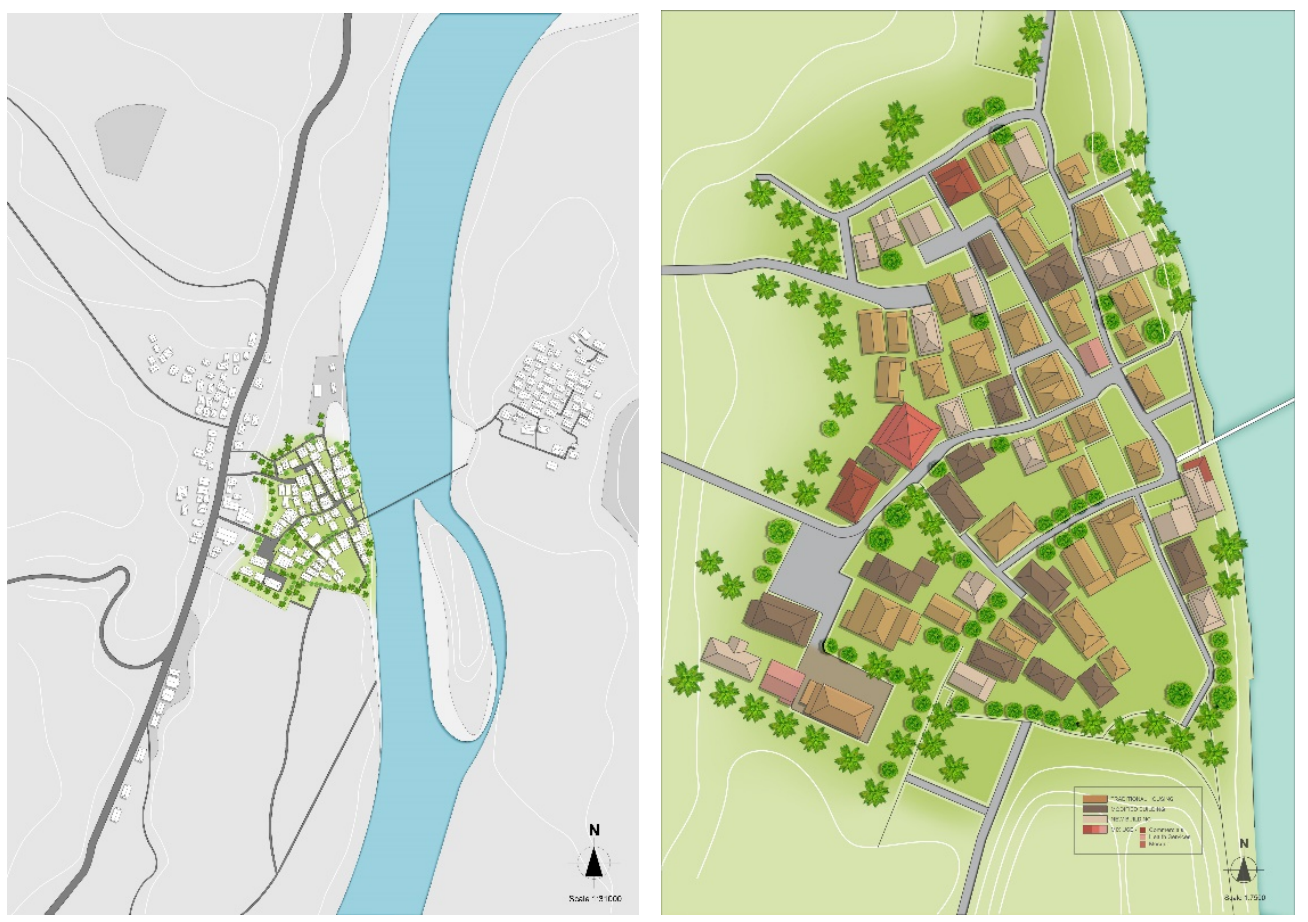

Fig 2. Map of settlement location and pattern of Lubuk Sepang Village (Source: Listen Prima, 2017)

Lubuk Sepang Village is a traditional village with a distinctive historical background. The location of this village is near Lematang River in Lahat Regency, South Sumatera Province. The riverside location influences the settlement, not only in terms of accessing but also view and orientation of the buildings in this village. The buildings are dominated by traditional houses called "Rumah Panggung." "Rumah" means house and "Panggung" means stage, since its floor has a lifted structure from ground. Meanwhile, local people called it "Rumah Baghi" as well; "Baghi" means old.

The traditional house in Lubuk Sepang Village is not only lifted from ground but also dominated by traditional wood structures. Other distinctive features include big doors, repetitive windows, and elevated roof. This design (Fig 4) is adapted to local tropical climate. 


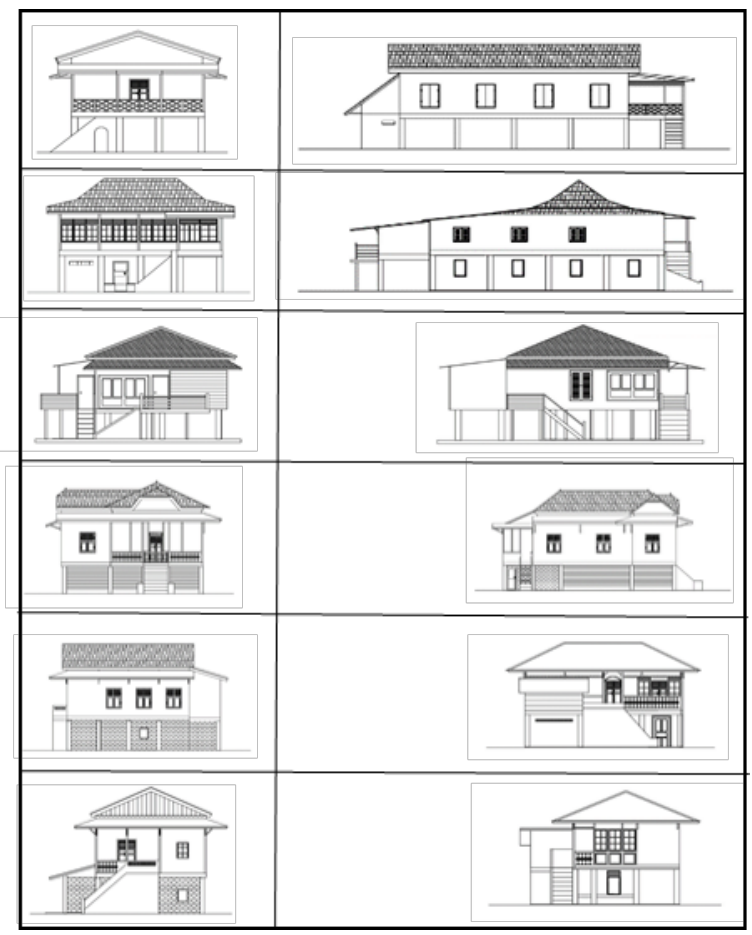

Fig 3. Traditional houses in Lubuk Sepang Village (Source: Listen Prima, 2017)

In Lubuk Sepang Village, the traditional houses build by using wood as a dominant material for its structure, floor, wall, roof and details or ornaments. The dominance of wood material influence by history of settlement. The settlement was built by open forest and the local people used woods for the materials, then an area became a new settlement. The location was chosen according to the proximity to water sources as main significant elements in the local people's life and continues to be a centre of daily activities. It is not only source of drinking but also mode of local transportation, source of agriculture needs, as well as sanitation and other daily needs.

The other special characteristics of the traditional houses in Lubuk Sepang Village is in details or ornaments of the houses. It is potential to be developed and marketed as other adapted forms of local production or home industry, such as handcraft, souvenir, etc. The detail or ornament (Fig 4) are handmade by local people. Those have been created based on traditional art, such as the flower pattern as an aesthetic symbol and animal forms as a power symbol. The ornaments usually are located in the front of the houses, in the frame of doors and frame of windows. 

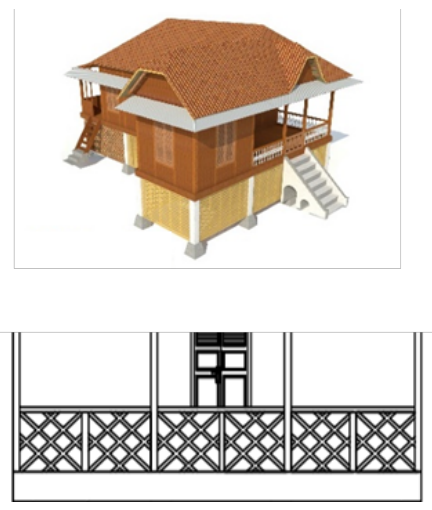
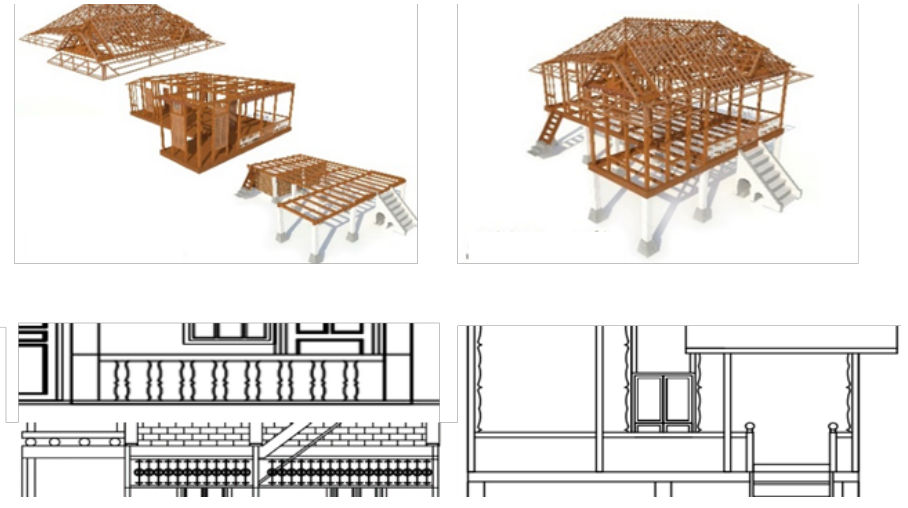

Fig 4. The structure and ornaments of traditional houses in Lubuk Sepang Village (Listen Prima,

2017)

Besides the distinctive historical background and the architectural heritage building and sites, local values such as unique cooking, ceremonial, and ritual traditions daily and as well as natural resources of Lubuk Sepang village offer a refreshing change from urban areas. The local people still perform the local values. The activities of the local people may create a centre of learning for tourists as well as preserving the local knowledge. This is also a way to valorise and develop the local values, especially for the heritage richness.
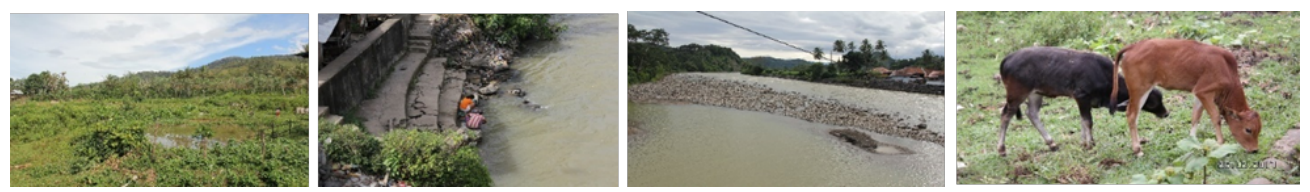

Fig 5. Natural resources in Lubuk Sepang Village (Listen Prima, 2017)

Considering the local people as component of the local potential in the village alliance, open-ended interviews have been conducted to analyse roles of the local people in local development. The interviewees are the owners of the heritage houses in Lubuk Sepang village. Lubuk Sepang village is the axis of the alliance since the idea of the protecting, valorising, and developing of the architectural heritage comes from its existence and local potential.

Result of the interviews from the 63 interviewees represents the local voice regarding the advancement of the sustainable tourism in the village alliance. 


\section{The percentage of highlight points of the interview}

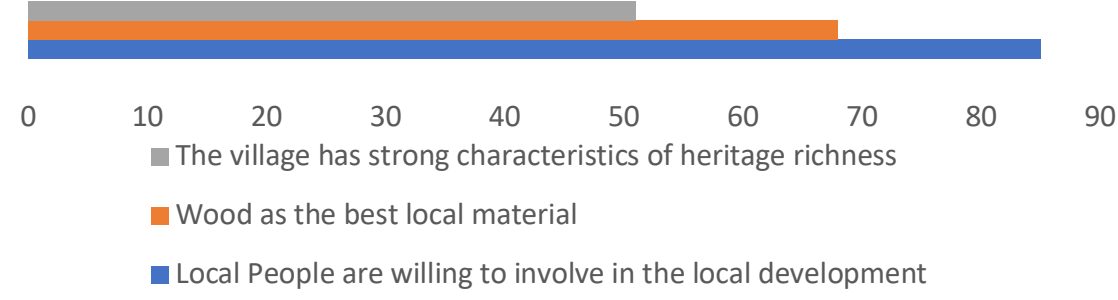

Fig 6. The percentage of highlight points of the interview in Lubuk Sepang Village (Listen Prima, 2018)

Highlighted points in graphic are some of many questions in the interviews among the residents. The interviews outlined the local capacities of the village based on the local people's perspective. The questions are indicative of thoughts regarding their settlement and neighbourhood, as well as opinions about spatial and local development for future dynamics.

The graphic shows percentage of three issues. The first issue is awareness of the local people that the village has strong characteristics of heritage richness, both material and immaterial. This is a significant indicator of how the local people understand the potential richness to be protected, valorised and developed. The data shows that $51 \%$ of the local people are fully aware that their village has strong characteristics of architectural heritage. The second issue is an opinion that wood is the best local material, especially for construction. This opinion is analysed in terms of the significance of local natural resources. This point shows that the forest plays an important role for the local development. Regarding existence of the heritage buildings, this opinion is also important since the heritage buildings built with the wood as the dominant materials. So, there is strong relevance between the existence of heritage buildings and the awareness of the local people and sustainability of the wood stock in the village alliance. $68 \%$ of the local people strongly agree that wood is the best material for construction, especially for the local houses. The third point is willingness of the local people to be involved in spatial and local development planning. It is urgent that local people are the main actors in any development programs, especially in the advancement of a sustainable tourism. Based on the interviews, $85 \%$ of local people are willing to be involved in any programs of development. This means that the local people's willingness is a significant contribution for the local development in the village alliance.

Regarding potentials of cultural heritage tourism in Lubuk Sepang Village as a village alliance, it is significant to define limits of its development. The limits are mostly related to infrastructure, which is challenged by its existing location. The location is divided by a river, making the connection between the villages more difficult.

Nature resources, especially regarding forest production of wood also provide a challenge. The local people struggle to keep original materials and construction, because of a shortage of the local woods. It is due to lack of management of wood production and distribution. As a result, it makes the local wood is more expensive. Dominance of some 
groups or companies in market practices in local area have influenced the cost of related products as well, for example materials and tools for renovating and cleaning of wood materials. Thus, it boosts costs for daily maintenance of the traditional houses for local people.

Another challenge is coming from human resources. Recently, case study area has been facing challenges lack of skilled person who can build the traditional houses. The skills required to build the traditional houses are mostly handed down by the older generation, who inherited/learned them from their parents/elders. Recently, there are not many young people who are interested in that skill and knowledge. Additionally, urbanisation occurs among the younger generation especially, who seek for better education, jobs, entertainment, etc. Hence, phenomena of modern perspective also threaten the existence of the traditional settlement in this village. Some of the local people tend to idealize modernization as a more developed or prosperous life and then compete to show it, including in house modifications, both exterior and interior elements.

Based on analysis of the local potential related to sustainable local development framework's, as well as the general limits of development in the case study area above, SWOT analysis examines all elements of local development to clarify significant elements in the case study area. It classifies components of relevant elements for the sustainable tourism scenario into three big groups of assessment: Space, Socio Economic Values, and Spatial Planning and Government (Table 1). The space components consist of spatial structure, settlement, natural resources, and infrastructures. The social-economic values consist of social, economic as well as politics and historical values. Other group components consist of spatial planning, organization of citizens, and planning instruments.

Table 1. The local potential of Lubuk Sepang Village (Listen Prima, 2018)

\begin{tabular}{|c|c|c|c|}
\hline \multicolumn{2}{|c|}{ Strength } & \multirow[b]{2}{*}{$\begin{array}{l}\text { Opportunities } \\
\text { 1. The vast capacity of agriculture as } \\
\text { a primary sector of development } \\
\text { 2. Tremendous potential of steam, } \\
\text { geothermal and solar power } \\
\text { energy }\end{array}$} & Thread \\
\hline Space & $\begin{array}{l}\text { Spatial } \\
\text { Structures }\end{array}$ & & $\begin{array}{l}\text { 1. Seasonal planting } \\
\text { and harvesting; } \\
\text { water shortage in dry } \\
\text { season and high } \\
\text { volume of rainfall in } \\
\text { raining season. } \\
\text { 2. No local expert to } \\
\text { ratified energy } \\
\text { alternative project }\end{array}$ \\
\hline & Settlement & $\begin{array}{l}\text { 1. Traditional villages with } \\
\text { distinctive characteristics of } \\
\text { material and immaterial heritage } \\
\text { 2. Specific sceneries of location, } \\
\text { such as near a river, hills, etc. }\end{array}$ & $\begin{array}{l}\text { 1. Modern perspective } \\
\text { eliminates its social } \\
\text { and cultural values } \\
\text { 2. Extension of } \\
\text { settlement area due } \\
\text { to an increase of } \\
\text { population number }\end{array}$ \\
\hline & $\begin{array}{l}\text { Natural } \\
\text { Resources }\end{array}$ & $\begin{array}{l}\text { 1. Complex biodiversity of flora and } \\
\text { fauna } \\
\text { 2. Many productive and natural } \\
\text { forest areas as locations of wood } \\
\text { production as well as for water } \\
\text { catchment area }\end{array}$ & $\begin{array}{l}\text { 1. Transition of } \\
\text { agriculture land to } \\
\text { settlement or } \\
\text { changes of plants in } \\
\text { the same land } \\
\text { 2. Threat of disasters, } \\
\text { such as landslides } \\
\text { due to location }\end{array}$ \\
\hline
\end{tabular}




$\begin{array}{llll}\begin{array}{l}\text { Infrastructu } \\ \text { re }\end{array} & \begin{array}{l}\text { Infrastructure network } \\ \text { alternative access }\end{array} & \text { and } & \begin{array}{l}\text { Difficult location } \\ \text { across the river }\end{array}\end{array}$

\begin{tabular}{|c|c|c|c|}
\hline \multirow[t]{4}{*}{$\begin{array}{l}\text { Social } \\
\text { Economic } \\
\text { Issue }\end{array}$} & Social & $\begin{array}{l}\text { Strong social relation in society such } \\
\text { as cooperation, etc. }\end{array}$ & $\begin{array}{l}\text { Traditional way of } \\
\text { thinking, especially } \\
\text { elderly who reject } \\
\text { changes }\end{array}$ \\
\hline & Economic & $\begin{array}{l}\text { Autonomous local economic and } \\
\text { agricultural sector, as well as other } \\
\text { sectors of industry, tourism, etc. }\end{array}$ & $\begin{array}{l}\text { 1. Limited land for } \\
\text { agriculture } \\
\text { 2. Young generation } \\
\text { less interested in } \\
\text { farming }\end{array}$ \\
\hline & Political & $\begin{array}{l}\text { The practice of transparent } \\
\text { government, such as an election of } \\
\text { the head of village }\end{array}$ & $\begin{array}{l}\text { Dominance of political } \\
\text { practice by some } \\
\text { parties }\end{array}$ \\
\hline & History & $\begin{array}{l}\text { Same historical background of } \\
\text { communities }\end{array}$ & $\begin{array}{l}\text { Less } \\
\text { knowledge/uneducated } \\
\text { people }\end{array}$ \\
\hline \multirow[t]{3}{*}{$\begin{array}{l}\text { Spatial } \\
\text { Planning } \\
\text { and } \\
\text { Governm } \\
\text { ent }\end{array}$} & $\begin{array}{l}\text { Spatial } \\
\text { Planning }\end{array}$ & $\begin{array}{l}\text { 1. Spatial planning applied from } \\
\text { national, province and regional } \\
\text { level } \\
\text { 2. Focus on productive land of each } \\
\text { area, such as agriculture and } \\
\text { mining } \\
\text { 3. Management of some potential } \\
\text { area to support local economic } \\
\text { development, such as registered } \\
\text { objects for protection, village } \\
\text { fund allocation for an equal } \\
\text { development, etc. } \\
\text { 4. Detail requirement and regulation } \\
\text { for space utilization (license, } \\
\text { incentive, sanction) }\end{array}$ & $\begin{array}{l}\text { Overlap of local } \\
\text { regulation } \\
\text { implementation }\end{array}$ \\
\hline & $\begin{array}{l}\text { Organizati } \\
\text { on of } \\
\text { Citizen }\end{array}$ & $\begin{array}{l}\text { The citizen has practised in } \\
\text { organization activities }\end{array}$ & $\begin{array}{l}\text { Non-cooperative local } \\
\text { people for their } \\
\text { properties } \\
\text { management, such as } \\
\text { for heritage building to } \\
\text { support tourism sector }\end{array}$ \\
\hline & $\begin{array}{l}\text { Planning } \\
\text { Instrument }\end{array}$ & $\begin{array}{l}\text { Each village has local governance } \\
\text { instruments (head, secretary, other } \\
\text { supported position) as } \\
\text { representatives of the local people }\end{array}$ & $\begin{array}{l}\text { Dominance of some } \\
\text { people, groups }\end{array}$ \\
\hline
\end{tabular}


Table 2. The challenges of local development in Lubuk Sepang Village (Source: Listen Prima, 2018)

\begin{tabular}{|c|c|c|c|}
\hline \multicolumn{2}{|c|}{ Weaknesses } & Opportunities & \multirow[b]{2}{*}{$\begin{array}{l}\text { Threat } \\
\text { 1. Unbalanced } \\
\text { development of the } \\
\text { local area } \\
\text { 2. Energy crisis }\end{array}$} \\
\hline Space & $\begin{array}{l}\text { Spatial } \\
\text { Structure } \\
\text { S }\end{array}$ & $\begin{array}{l}\text { 1. Potential capital village/city as } \\
\text { activities centre } \\
\text { 2. Intensification of technology } \\
\text { facilities, such as internet }\end{array}$ & \\
\hline & $\begin{array}{l}\text { Settlemen } \\
\mathrm{t}\end{array}$ & $\begin{array}{l}\text { Chances of environmental } \\
\text { management, such as recycle and } \\
\text { waste system }\end{array}$ & $\begin{array}{l}\text { Environmental health } \\
\text { is low }\end{array}$ \\
\hline & $\begin{array}{l}\text { Natural } \\
\text { Resource } \\
\text { S }\end{array}$ & $\begin{array}{l}\text { Enhancement of control and } \\
\text { management of protected area }\end{array}$ & $\begin{array}{l}\text { Natural disaster: } \\
\text { landslide }\end{array}$ \\
\hline & $\begin{array}{l}\text { Infrastruc } \\
\text { tures }\end{array}$ & $\begin{array}{l}\text { Development of infrastructure, such } \\
\text { as water access and transportation }\end{array}$ & Difficult location \\
\hline \multirow{4}{*}{$\begin{array}{l}\text { Social } \\
\text { Economic } \\
\text { Issue }\end{array}$} & Social & $\begin{array}{l}\text { Sustainability of a } \\
\text { demographical composition }\end{array}$ & $\begin{array}{l}\text { Slow of local } \\
\text { development }\end{array}$ \\
\hline & $\begin{array}{l}\text { Economi } \\
\mathrm{c}\end{array}$ & $\begin{array}{l}\text { Development of economic sector } \\
\text { beyond agriculture }\end{array}$ & $\begin{array}{l}\text { Poor economic } \\
\text { condition }\end{array}$ \\
\hline & Political & $\begin{array}{l}\text { Development of the education and } \\
\text { knowledge about political view }\end{array}$ & $\begin{array}{l}\text { No involvement of the } \\
\text { local people }\end{array}$ \\
\hline & History & Protection of local history & $\begin{array}{l}\text { Historical values are } \\
\text { dismissed }\end{array}$ \\
\hline \multirow{3}{*}{$\begin{array}{l}\text { Spatial } \\
\text { Planning } \\
\text { and } \\
\text { Governm } \\
\text { ent }\end{array}$} & $\begin{array}{l}\text { Spatial } \\
\text { Planning }\end{array}$ & $\begin{array}{l}\text { Ratification of spatial planning in } \\
\text { villages coverage }\end{array}$ & Undeveloped areas \\
\hline & $\begin{array}{l}\text { Organizat } \\
\text { ion of } \\
\text { Citizen }\end{array}$ & $\begin{array}{l}\text { Enhancement of focus and variations } \\
\text { of local communities }\end{array}$ & $\begin{array}{l}\text { Local people do not } \\
\text { have enough facilities } \\
\text { to develop }\end{array}$ \\
\hline & $\begin{array}{l}\text { Planning } \\
\text { Instrume } \\
\text { nt }\end{array}$ & $\begin{array}{l}\text { 1. Implementation of space } \\
\text { utilization (license, incentive, } \\
\text { sanction) } \\
\text { 2. Potential of human resource as a } \\
\text { planning instrument }\end{array}$ & $\begin{array}{l}\text { 1. Illegal movement } \\
\text { 2. Minimum works of } \\
\text { the local } \\
\text { instruments }\end{array}$ \\
\hline
\end{tabular}

In the SWOT analysis, criteria are divided based on main elements of the local development. Thus, all significant input indicates urgent need and most appropriate approach to boost local strength and minimize weaknesses.

\subsection{The Sustainable Tourism Scenario}

Analyses of the research uses a village alliance as a framework. The village alliance (Figure 6) is an innovative idea defined by location, historical background, as well as social, economic and culture, and local potential of each village. The purpose is to collect information about each village to holistically offer the area for integrated tourism based on sustainable development concept. Since, the sustainable development is a manifestation of the possible future approaches, especially in the local area. It is not merely about the single village, but a link between the local potential of architectural heritage in the village alliance into an advancement perspective of a sustainable tourism scenario. 


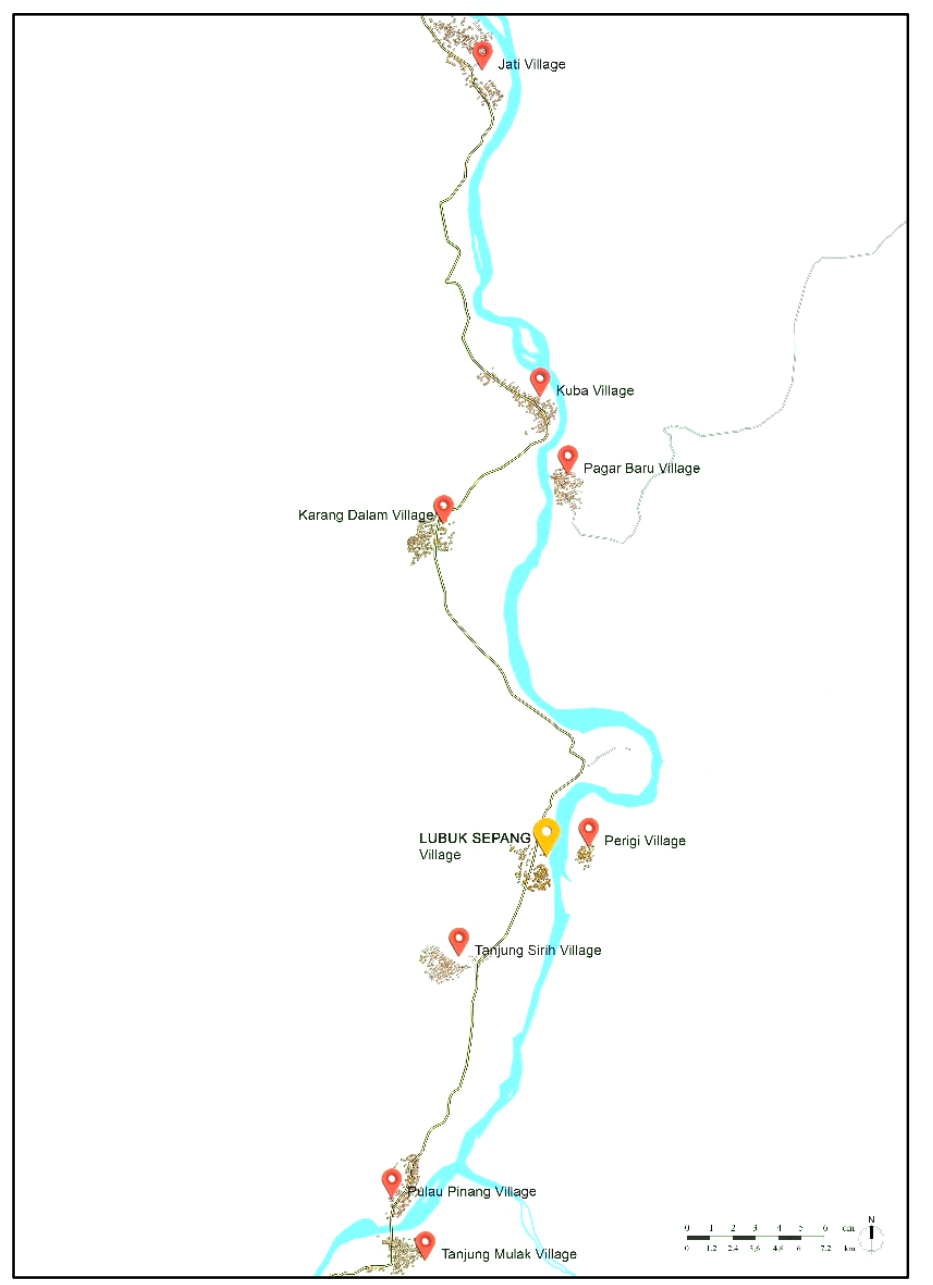

Lubuk Sepang Alliance

consists of 9 villages, such as:

1. Jati

2. Kuba

3. Pagar Batu

4. Karang Dalam

5. Perigi

6. Lubuk Sepang

7. Tanjung Sirih

8. Pulau Pinang

9. Tanjung Mulak

Fig 6. Map of Lubuk Sepang Village and its alliance (Listen Prima, 2018)

Hence, processes of scenario planning are starting from defining principal aim and planning objective. The planning objective covers all components of sustainability development concept, such as spatial, social, culture and education, ecology, and economy. All those components are integrated as complex elements that have to be defined and fulfilled in scenario. Then, an outline of the sustainable tourism scenario is evaluated to define its interesting and critical points.

In this scenario, the exploration of the sustainable tourism scenario is divided into two scales of sub scenarios based on targeted tourist type and scale of its development.

\subsubsection{Domestic Tourism}

In this scenario, local Indonesians are the target market. This idea comes from a complex problem of urbanisation, in which people in many big cities tend to search for new areas as a refreshing alternative. This phenomenon of rural tourism is a big opportunity for development. This concept provides an integrated place consists of some of villages with various local characteristics. It offers more sustainable activities than a single village can. In 
contrast, current tourism activities are commonly focused on a single area and for only a short period, such as Taman Pelangi (Rainbow Park) in Jakabaring District and Danau Teluk Gelam (Teluk Gelam Lake) in Tanjung Gelam District, South Sumatera Province.

Tourism activities in this sub scenario consist of several offers based on the local potential, such as cultural heritage and nature tourism. The cultural tourism provides architectural heritage tourism objects, such as heritage design, details, and ornaments. Besides material, components of immaterial heritage are also strengthening the cultural heritage tourism, such as local knowledge of heritage buildings, history, wood construction, as well as daily activities, rituals, and ceremonies. Additionally, natural resources in the village alliance as strong characteristics of the village alliances offer local leisure. Seasonal activities such as tracking, river boat, paddy plantation, etc. allow tourists to interacted with natures.

Furthermore, local development scale in this sub scenario sets a minimum of new buildings or facilities development. As supporting facilities, local hotels provide limited accommodation capacity, which minimizes mass development in the village. Hence, it provides a possibility for local people to manage activities autonomously under supervision of local government.

\subsubsection{International Tourism}

The target of this scenario is to attract tourists from around the world. This sub scenario not only envisions the village alliance as an escape place for people from big city in Indonesia but also positions the village alliance as a main tourist destination in Southeast Asia.

The sub scenario of international tourism offers wide ranges of activities. The heritage richness in a wider context becomes not only an object but also as a subject. It provides possibilities for visitors to be involved. The tourists are kindly invited to take part, such as in architectural heritage building reconstruction, agriculture activities, daily activities such as cooking, handcrafting, etc. Besides, activities in nature are designed with more active programs through nature sport. Hence, other programs provide facilities for the tourists to stay in local communities.

Regarding the target of tourist number and various activities, this sub scenario needs a maximum or total development of the village alliance. The development is mainly for supporting facilities, especially accommodation. To accommodate tourists, facilities will be built with characteristics of the traditional local architecture/houses, such as wood designs and elevated structures. The maximum accommodation in settlement can be managed with a concept of diffuse hotels that may facilitate the tourist with enough space to interact with local communities and other visitors. Thus, local characteristic is part of the development concept.

Hence, this sub scenario would involve many parties to manage and develop it with local people as actors. However, management and supervision would be needed through interventions of local government, academics, education institution in tourism field, and governmental organizations as third parties. As marketing businesses, this scenario possibly opens chances to make a cooperation with expertise and tourism actors such as agencies, etc. Each of sub scenarios have specific principal aim and planning objective. The sustainable tourism scenario is an explorative way to face challenges of regional transformations. Thus components of the planning objective include details about specific requirements of development, not only for spatial but also other components of daily life such as social, culture and education, ecological as well as economic (Table 3). 
Table 3. The sustainable tourism sub scenario (Listen Prima, 2018)

\begin{tabular}{|c|c|c|c|c|c|c|c|}
\hline \multirow[t]{2}{*}{ Scenario } & \multirow[t]{2}{*}{ Principal Aim } & \multicolumn{4}{|c|}{ Planning Objective } & \multicolumn{2}{|c|}{$\begin{array}{l}\text { Evaluation } \\
\end{array}$} \\
\hline & & Spatial & $\begin{array}{c}\text { Social, } \\
\text { culture } \\
, \\
\text { educati } \\
\text { on }\end{array}$ & Ecology & Economy & Interesting Points & Critical Points \\
\hline $\begin{array}{l}\text { Sustainable } \\
\text { Tourism } \\
\text { Scenario }\end{array}$ & $\begin{array}{l}\text { Developing the } \\
\text { local potential } \\
\text { for a sustainable } \\
\text { tourism sector }\end{array}$ & & & & & & \\
\hline $\begin{array}{l}\text { Domestic } \\
\text { Tourism }\end{array}$ & $\begin{array}{l}\text { A new } \\
\text { atmosphere for } \\
\text { people forms } \\
\text { urban areas (big } \\
\text { cities) in } \\
\text { Indonesia }\end{array}$ & $\begin{array}{l}\text { Tourism } \\
\text { destinati } \\
\text { on in the } \\
\text { region. } \\
\text { - Public } \\
\text { facilities } \\
\text { to } \\
\text { support } \\
\text { tourism } \\
\text { activities }\end{array}$ & $\begin{array}{l}\text { - Ope } \\
\mathrm{n} \\
\text { and } \\
\text { ada } \\
\text { ptiv } \\
\mathrm{e} \\
\text { soci } \\
\text { ety } \\
\text { Edu } \\
\text { cati } \\
\text { on } \\
\text { pro } \\
\text { gra } \\
\text { ms } \\
\text { of } \\
\text { tour } \\
\text { ism } \\
\text { acti } \\
\text { vitie } \\
\text { s }\end{array}$ & $\begin{array}{l}\text { - Natural resources } \\
\text { as a subject for the } \\
\text { tourism. } \\
\text { - Practical } \\
\text { implementation of } \\
\text { sustainability } \\
\text { framework }\end{array}$ & $\begin{array}{l}\text { - Autonom } \\
\text { ous } \\
\text { economic } \\
\text { condition } \\
\text { - Alternativ } \\
\text { e } \\
\text { activities } \\
\text { as local } \\
\text { economy } \\
\text { creative. }\end{array}$ & 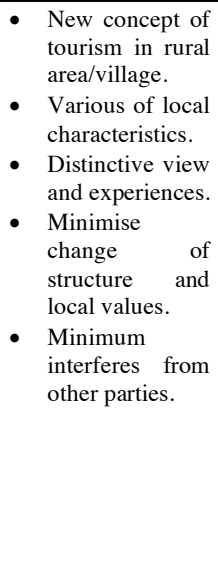 & $\begin{array}{l}\text { - Existence of } \\
\text { dominance } \\
\text { people and } \\
\text { groups. } \\
\text { - Interfere from } \\
\text { other parties } \\
\text { - Challenge of } \\
\text { sustain local } \\
\text { tourism. }\end{array}$ \\
\hline $\begin{array}{l}\text { Internation } \\
\text { al Tourism }\end{array}$ & $\begin{array}{l}\text { Huge number of } \\
\text { significant } \\
\text { national and } \\
\text { international } \\
\text { tourist as a main } \\
\text { tourist } \\
\text { destination in } \\
\text { Sumatera } \\
\text { Island. }\end{array}$ & $\begin{array}{l}\text { - Integrate } \\
\text { d villages } \\
\text { as a } \\
\text { tourism } \\
\text { destinatio } \\
\mathrm{n} \\
\text { - Mass } \\
\text { develop } \\
\text { ment of } \\
\text { public } \\
\text { facilities }\end{array}$ & $\begin{array}{l}\text { - Loc } \\
\text { al } \\
\text { valu } \\
\text { es } \\
\text { as a } \\
\text { subj } \\
\text { ect } \\
\text { of } \\
\text { tour } \\
\text { ism } \\
\text { as } \\
\text { well } \\
\text { as a } \\
\text { way } \\
\text { to } \\
\text { prot } \\
\text { ect } \\
\text { and } \\
\text { dev } \\
\text { elop } \\
\text {. } \\
\text { Imp } \\
\text { rove } \\
\text { a } \\
\text { prod } \\
\text { ucti } \\
\text { ve } \\
\text { and } \\
\text { skill } \\
\text { hum } \\
\text { an } \\
\text { reso } \\
\text { urce }\end{array}$ & 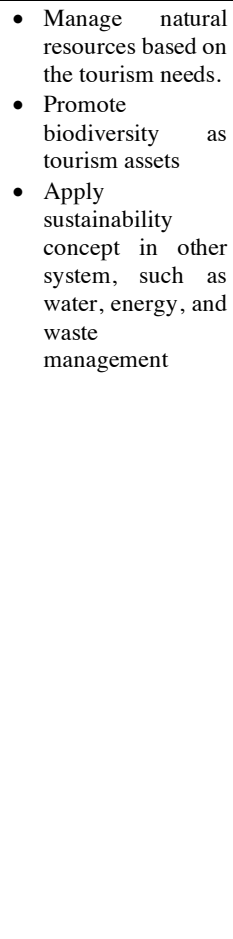 & $\begin{array}{l}\text { - A new } \\
\text { and } \\
\text { authentic } \\
\text { local } \\
\text { economy } \\
\text { - Local and } \\
\text { regional } \\
\text { prosperity } \\
\text { as well as } \\
\text { national } \\
\text { contributi } \\
\text { on } \\
\end{array}$ & $\begin{array}{l}\text { - To Foster local } \\
\text { development as } \\
\text { well as national } \\
\text { tourism } \\
\text { development. } \\
\text { - To Support } \\
\text { program of } \\
\text { Indonesia } \\
\text { government to } \\
\text { balance the } \\
\text { development of } \\
\text { tourism out of } \\
\text { Java and Bali } \\
\text { island. } \\
\text { - New alternatives } \\
\text { of Indonesian } \\
\text { tourism } \\
\text { - Strengthen local } \\
\text { potential and } \\
\text { promote it to } \\
\text { international } \\
\text { perspectives }\end{array}$ & 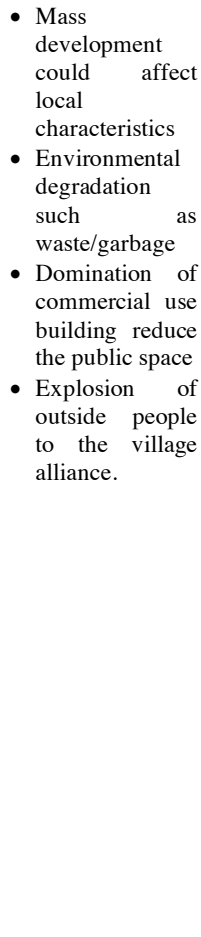 \\
\hline
\end{tabular}




\section{Discussion}

Analysis of local potential in case study area defines a proper method to face future challenges regarding richness of architectural heritage, local development, as well as natural resources. The case study method in this research has some points to discuss further. The complexity of variables regarding architectural heritage pose some challenges in establishing the inter-relationships among material and immaterial culture, local development components of social, economic, politic and governance, as well as natural resources in many forms of agriculture and farming, forestry, etc. This triggers to indefinite variable and parameters. The challenges are how to link parameters of those components into a sequence discussion to outline a result. Then, case study method uses multiple tools to fill gap of the result.

Results of the broad analysis allow for a more focused analysis of possible methods to maximise local development by valorising potential, solving its challenges and minimising risks both for people and environment. Besides, the analysis also guides the orientation toward future needs without neglecting present needs and keeps past values as a component of the local potential.

Furthermore, this research proposes the sustainable tourism scenario as an extension of cultural heritage tourism. The idea of sustainable tourism scenario is collaborating the potential of heritage richness of case study area of Lubuk Sepang Village, both material and immaterial as objects of cultural heritage tourism with other important elements of local development and natural resources, such as local knowledge, food, and wood production.

\section{Conclusions}

Advancement of cultural architectural heritage must integrate method of protection, valorisation, and development. Analysis of local potential is necessary before constructing prospective method. The case study as methodological framework combines all components of architectural heritage, local development as well as natural resources in a perspective similar to sustainable tourism advancement.

Hence, an idea of a village alliance as a framework of analysis is more than just an outline of the case study into bigger scale, but also a way to implement more sustain method and integrated programs. The village alliance proposes an Integration of all related villages, in contrast to single approaches which may be difficult to sustain, like many practices in Indonesia. The village alliance supports the potential of each village while minimizing individual limitations. This alliance offers an innovative and applicative since it represents a dominant context of rural development area, especially in Indonesia.

Regarding future challenges, sustainable tourism scenario is outlined as an explorative approach. The scenario aims to integrate all the local potential in the village alliance to improve all sectors as planning objective. The sustainable tourism scenario is outlined based on case study analysis and considers richness of heritage as a prime potential resource. As a first milestone of scenario process, an initial evaluation of interesting and critical points is outlined.

However, this research is only one piece of the project, and will be integrated with another possible explorative scenario to define alternative approaches. Hence, the most suitable prospective scenario will ultimately be chosen for the protection, valorisation, and development of the local potential of heritage architecture in relation to other components of spatial and local development as well as natural resources in the case study areas. 


\section{Acknowledgement}

This research is supervised by Prof. Dipl.-Ing. Jörg Schröder, Faculty of Architecture and Landscape Science in Leibniz Universität Hannover, Germany, and funded by BUDI-LN Scholarship of Kemristikdikti-LPDP (Indonesian Endowment Fund for Education). The author is also grateful for comments from Zoe Vercelli, MA., Fachsprachenzentrum in Leibniz Universität Hannover, Germany, referee from Associate Prof. Maddalena Ferreti, Department of Civil and Building Engineering, and Architecture, Università Politecnica delle Marche, Ancona, Italy, and support from academics/staffs of Department of Architecture, Faculty of Engineering, Universitas Sriwijaya, Indonesia.

\section{References}

1. A. Magnaghi. The Urban village: a charter for democracy and local self-sustainable development (Zed, London, 2000)

2. European Commission, Cultural Heritage Counts for Europe Report, 9 (CHCfE Consortium, Krakow, 2015)

3. K. McCormik, S. Anderberg, L. Coenen, L. Neij. Advancing Sustainable Urban Transformation, Journal of Cleaner Transformation, 50, 1 (2013)

4. M. Stojanovic, P. Mitkovic, P, M. Mitkovic. The Scenario method in urban planning, Facta Universitatis, Series: Architecture and Civil Engineering, 12(1), 81-82 (2014)

5. R.K. Yin. Studi Kasus: Desain \& Metode (RajaGrafindo Persada, Jakarta, 1996)

6. L. Groat, D. Wang. Architectural Research Method, 421 (John Wiley \& Sons, New Jersey, 2013)

7. M. Jonas. A Scenario for Design. Design Issues, 17(2), 64 (2018)

8. R. E. Tevis, Robert. Creating the Future: Goal Oriented Scenario Planning, Future, 42, 339 (2009)

9. T. Frank, Envisioning Our First Principles Predecessors: Legacies of Climatization in Ancient Anatolian Structures, in A. K. Walczak (ed.), Envisioning Architecture: Image, Perception, and Communication of Heritage (Lodz University of Technology, Lakowa, 2015)

10. J. Urry. Gazing on History, in D. Boswell, J. Evans (eds.), Representing the Nation: A Reader, Histories, Heritage and Museums, (Routledge, London, 1999)

11. F. Choay, The Invention of the Historic Monument, 120-121 (Cambridge University Press, Seuil, 1992)

12. K. Robin, Tradition and Translation: National Culture in Its Global Context, in D. Boswell, J. Evans (eds.), Representing the Nation: A Reader, Histories, Heritage and Museums, London: (Routledge, London, 1999)

13. R. Hewison, The Climate of Decline, in D. Boswell, J. Evans (eds.) Representing the Nation: A Reader, Histories, Heritage and Museums (Routledge, London, 1999)

14. N. D. Morpeth, H. Yan, Tourism Planning, in N.D. Morpeth, H. Yan, Planning for Tourism, towards a Sustainable Future, 8 (CABI, Wallingford, Oxfordshire, Boston, MA, 2015)

15. S. Jelic, M. Jandric, M. Zivkovic, Z. Milovancevic, Determinant of Household and Regional Rural Areas, Agriculture \& Forestry, 61, 143-148 (2015)

16. S. Sharma, Globalisation and Rural Development, Indian Journal of Agricultural Economics, 68(2), 265-267 (2013) 
17. J. Schroder, Towards an Architecture of Territories, in J. Schroder, M. Carta, M. Ferretti, B. Lino (eds.), Territories, Rural-Urban Strategies, 14-35 (Jovis, Berlin, 2017)

18. C. Hunter, Sustainable Tourism as an Adaptive Paradigm, Annals of Tourism Research, 24 (4), 850- 867 (1997)

19. W. Slee, H. Farr, P. Snowdon, Sustainable Tourism and the Local Economy, in M. J. Stabler (ed.), Tourism and Sustainability: Principles to Practice, 69-87 (CABI, Wallingford, 1997)

20. World Heritage Convention, UNESCO, Sustainable Tourism; UNESCO World Heritage and Sustainable Heritage Tourism Programme, https://whc.unesco.org/en/tourism/, Accessed Date 09/04/2018 (2018)

21. Organisation for Economic Co-operation and Development (OECD) Working Papers, Tourism Strategies and Rural Development, II, 4 (OECD, Paris, 1994)

22. H. Hapke, Rural Development, in B. Warf (ed.), Encyclopedia of Geography (SAGE, Los Angeles, 2010) 